\title{
MAIN STRATEGIES FOR THE DEVELOPMENT OF MARKETING COMMODITY POLICY
}

\author{
Ukrainian State University of Chemical Technology, Dnipro, Ukraine
}

\begin{abstract}
The article reviews theoretical approaches to the definition of the essence of the category of marketing commodity policy. The task, structure and main components of the commodity policy in the modern economic conditions are defined. The main objectives of marketing commodity policy are analyzed. The strategy of changes in the management of marketing commodity policy of the enterprise is proposed, namely: strategy of support, strategy of modification and strategy of restoration, which will promote increase of competitiveness of goods, product portfolio of the enterprise, and its image. Marketing commodity policy consists of three parts: product development (creation of a new product or modification of existing ones); Service maintenance (ensuring the stability of the relevant characteristics of the goods in demand, especially important is the product quality control at all stages from design to sale) and elimination (goods removal from production).
\end{abstract}

Keywords: commodity, commodity policy, marketing commodity policy, strategy, commodity strategy.

DOI: $10.32434 / 2415-3974-2018-8-2-104-109$

\section{Introduction and problem statement}

In a market economy, the priority tasks of modern enterprises are the effective organization of production of goods and services, ensuring sustainable competitive advantages, increasing the market share and, as a consequence, improving the results of financial and economic activity. A key element in achieving commercial success of the company in the short and long term is the marketing commodity policy. Only products that are competitive in the market can provide a sustainable advantage of the company's presence on the market. Therefore, the question of choosing an active marketing product strategy is very relevant today.

\section{Recent researches and publications analysis}

The works of such Ukrainian and foreign scientists as O.V. Zozulev, N.S. Kubyshina, S.A. Solntsev, V.Y. Kardash, P. Kotler, L.V. Balabanova, I.A. Pavlenko, O.K. Shafalyuk, G.O. Kholodnuy, G.M. Shumskaya, Z.S. Kaira, S.M. Illyashenko, G.O. Peresadko, O. Walker, H. Boyd, J.-K. Larche, J. Mullins, V.N. Koropukhina, D.V. Ostapenko, P.Y. Yurkovsky and others are dedicated to definition of the essence of the concept of «commodity policy» and the problem of its development at enterprises.

The purpose of this paper is to substantiate the features of the company's commodity policy and ways to improve it.

\section{Presentation of the main material}

The main element of the marketing complex is the product, on which the success of the market activity of the enterprise depends to a decisive extent.

The generally accepted definition of a product - the product of labor, made for sale - remains with the marketing approach. However, this is not so much about the role of goods in its exchange for money, but about the ability to use, to consume the latter. In other words, the product in the marketing system is, first of all, the product with which the producer is entering the market, as well as a way to satisfy the needs of the market.

There are five levels of goods that reflect the hierarchy of consumer value of goods. The first level is the key value, that is the advantage for the buyer. At the second level, the key value of the efforts of marketers turns on the main product. At the third level, the expected product is formed, namely, a set of characteristics for which the consumer is waiting for. At the fourth level, the marketer creates an improved product that exceeds the usual expectations of consumers. Competition unfolds on this level. At the fifth level there is a potential product and its 
improvements that are possible in the future. At this level, enterprises are looking for new ways to satisfy the needs and improve their product.

Thus, the product is the main element of the effective functioning of the enterprise and crucial in satisfying the customers' needs. This is evidenced by the fact that if the product does not meet consumer inquiries or loses its characteristics to competitors, then hopes for its success in the market will be virtually nullified.

Therefore today there is an important task before the Ukrainian enterprises, which is to effectively organize the production of goods and services, relying on the formation of marketing support for this process by the optimal use of marketing tools [1].

The term marketing commodity policy is quite wide and covers various aspects of product strategy and tactics of the company. This is the product range formation, the modification of existing products, decommissioning, the development and launch of new products or services, the provision of an adequate level of their quality and competitiveness..

N.V. Butenko explains that the marketing commodity policy consists of the following processes: product development, product service and elimination. The most important part of marketing commodity policy is the development of goods (services), since it allows you to break into the market, defeat competitors, maintain and expand the market, increase income and profits, etc. An important aspect in shaping such a policy is to ensure the sustainability of the relevant characteristics of the goods, control the quality of products and ensure an adequate level of product competitiveness [1].

Commodity policy of the enterprise, as S.M. Ilyashenko notes, is the management of the product nomenclature, product range and separate product units, and the management of the commodity nomenclature is the modification of the product nomenclature and modification of assortment groups [2].

According to A.V. Voychak, commodity policy is a set of measures in which one or several goods are used as the main tools of production and sales activities for the company. Positive point of the author is connecting commodity policy directly to marketing, and the main tool of production and marketing activities of the company is the product [3].

According to S.S. Garkavenko, marketing commodity policy is a set of measures within one or several goods used as the main tools to achieve the goals of the company [4].

By definition of G.O. Kholodnuy, commodity policy involves a substantiated algorithm of action, which involves the definition of an enterprise's production program taking interests of consumers into account, the level of influence of competitors, production and other resource opportunities of the enterprise, as well as the stages of the product life cycle [5].

According to L.V. Balabanova, marketing commodity policy is the marketing activity of the enterprise, which is connected to the implementation of strategic and tactical measures to ensure the competitiveness of goods and the formation of a product portfolio in order to satisfy the needs of consumers and ensuring profit [6].

E.V. Krikavskiy believes that the marketing commodity policy involves a certain set of measures of the enterprise aimed at developing a new product and putting it on the market, as well as researching the individual components that provide this process [7].

Thus, agreeing with the definition of wellknown scientists, we can say that marketing commodity policy is a well-founded, purposeful algorithm and a complex of marketing actions, organizational and economic measures concerning the provision of competitiveness of any product and portfolio of goods, the forming of a strategy and tactics of their development taking into account the interests of consumers, the level of influence of competitors, production and other resource opportunities that will contribute to the more formal development of the enterprise.

Marketing commodity policy is shaped by the trade potential of the company considering its commodity climate. In turn, the commodity potential of the enterprise is a set of resource, marketing and managerial factors of the internal environment of the enterprise, which ensure its readiness and ability to formulate and implement the marketing commodity policy [9]. include:

The tasks of marketing commodity policy

- the formation and creation of an exclusive idea and the creation of a real new product, where the rest of the factors of marketing would be an exclusively additional (serving) character;

- the development of a new product and updating those products that already exist in the market;

- development of the product assortment, packaging and brands;

- ensuring the quality and competitiveness of goods;

- positioning of goods on the market;

- the life cycle of goods' analysis and forecasting [10].

The development and implementation of commodity policies requires compliance with the following conditions:

- a clear idea of the strategic objectives of production and sales activities of the enterprise; 
- perfect knowledge of the market and the nature of its requirements;

- a clear idea of their capabilities and resources (research, scientific and technical, production, sales, labor, etc.) in the present and in the future.

The process of forming a commodity policy should be based on a strategic approach, which involves the development of a long-term, promising course and should solve the following key tasks:

- optimization and restoration of the product assortment, while taking the life cycle of the product and the ratio of new and «old» goods in the assortment program into account;

- purposeful adaptation of the product assortment to the requirements of the target market and consumers;

- effective management of goods and venture capital; quality assurance and competitiveness of goods; development of new markets for the sale of existing and new goods; management of the process of developing and bringing new types of products to the market;

- strategic positioning of goods on the market;

- planning the process of withdrawal of goods that lose market positions from the production and (or) marketing program.

Commodity policy can not be separated from the real conditions of functioning and development of the environment of the enterprise, from the specifics of its production, commercial and marketing activities. All questions related to the formation of the strategy and tactics of the conduct of commodity policy, should be solved in accordance with market requirements and the behavior of competitors.

The absence of a well-founded commodity policy leads to instability of the assortment as a result of the influence of random or transient factors, loss of control over the competitiveness and commercial efficiency of goods.

The basic decisions taken in the system of management of commodity policy of the enterprise, are based on three levels:

- goods (brands);

- product assortment;

- product nomenclature.

Marketing commodity policy involves the implementation of a set of measures in which one or several products are used as the main tools for achieving the goals of the enterprise. The main components of commodity policy are the decision on the development of new products, their modification, maintenance or decommissioning (Figure) [11].

The most important part of marketing commodity policy is the development of goods. This concept envisages either the planning (creation) of new products that will allow the company to enter new markets or expand existing ones, to defeat

\begin{tabular}{|l|l|l|}
\hline $\begin{array}{l}\text { Development of new or } \\
\text { improved existing product } \\
\text { (product assortment) }\end{array}$ \\
\hline \hline $\begin{array}{l}\text { Increasing income and } \\
\text { profit }\end{array}$ \\
\hline \hline $\begin{array}{l}\text { Achieving competitive } \\
\text { advantages }\end{array}$ \\
\hline \hline $\begin{array}{l}\text { Access to new markets } \\
\text { market share }\end{array}$ \\
\hline $\begin{array}{l}\text { Increasing consumer } \\
\text { attention to the } \\
\text { product }\end{array}$
\end{tabular}

The main goals of marketing commodity policy of an enterprise 
competitors, to receive relevant revenues and profits, or to modify existing products, that is to change their properties and characteristics that will make it possible for them to constantly attract the attention of consumers and as a result - to preserve long sales and revenue time.

Service is the stability maintenance of the relevant characteristics of goods, their compliance with the established standards. The main thing in this part of the marketing commodity policy is the control over the quality of products, the timely informing for the need to improve the production, the implementation of measures that preserve the characteristics of goods during the commodity movement and sales.

Elimination is the process of removing obsolete (the one that has ceased to be in active demand) products from the production and market. The main task of this part of the marketing commodity policy is to optimize the processes of eliminating the obsolete goods from the market, to timely stop their production, to reconcile the costs of the production and sale of goods, the demand for which is constantly falling, with an income decrease from the sale of goods which are still available and on which you can expect at least in the near future [12].

It is advisable to take certain criterias into account for deciding a withdrawal of a product from the market. The main ones are:

- the economic importance of the product for the company (share in circulation, income from sales, profitability);

- product position on the market (market share, market potential);

- future prospects of the product (life cycle stage, expected technological changes).

Direct withdrawal of the goods from the market is carried out by the following measures:

- gradual decrease in production and sales costs and a following decrease in sales of an outdated product;

- a sharp decrease in marketing costs in order to reduce overall costs and save profits in the final stages of HCT;

- focusing marketing efforts on the strongest and most attractive segment of the market (while the rest of the segments are being pulled out from the sales phase);

- removal of separate assortment positions from the product line and concentrating resources on the most favorable positions for the company;

- the enterprise's transition from one operating area to another in order to concentrate on prioritized, perspective and effective directions [12].

In today's operating environment, there are problems that negatively affect the effective management of marketing commodity policies:
- high incosistency of the external environment; negative state of the macro environment;

- low solvency of the population; violation of consumer rights and imperfect system of their protection;

- availability of counterfeit goods of poor quality (an element of unfair competition);

- Chaotic changes in prices for raw materials, customs tariffs for imported goods;

- saturation of the domestic market with imported goods; unfavorable lending conditions for small and medium businesses;

- weak orientation of business activity for marketing;

- Complexity of marketing researches; the underdevelopment of the system and the process of strategic, complex and systematic approaches to enterprise management; weak social orientation of enterprises.

The high degree of uncertainty of the environment causes increased attention to the question of substantiation of choosing a commodity strategy that would ensure the market success of industrial enterprises.

Commodity strategy is a long-term course of enterprise development, a way of achieving the goals it defines for itself, guided by its own considerations within its policy.

To develop a product strategy, each business must understand such important elements of its activity: mission; competitive advantages; peculiarities of business organization; markets where the company operates; product (service); resources; the structure; production program; organization culture.

With this in mind, the following strategies for the development of commodity policies are distinguished [2]:

- a support strategy that involves the continuous improvement of the product potential of the enterprise, the monitoring of new technologies in marketing, management and their implementation in the processes of marketing commodity policy management, that does not require significant changes; paying attention to the strategic control over the implementation of strategies in the blocks of resource, marketing and management of product potential, or at the level of the determined factors of each unit of commodity potential, which has a high state of development;

- a modification strategy that requires minor changes in the resource, marketing and management blocks of the product potential or at the level of the identified factors of each unit of product potential, which has an average development status; strengthening of strategic and tactical control over the implementation of strategies in the commodity potential of the enterprise); 
- an upgrade strategy that requires significant and radical changes in all product potential or at the level of identified factors of each unit of product capacity that has a low development status; strengthening of the preliminary, current, final, operational, tactical tactical and strategic control over the implementation of strategies in the commodity potential of the enterprise; the involvement of leading specialists in the field and the improvement of the skills of workers.

Thus, the marketing commodity policy is based on the following principles:

- orientation of all enterprise activity areas to satisfy the needs of buyers for the purpose of selling products and receiving profits;

- purposeful and active influence on demand, its development; flexible production response to demand changes and customer demands, quick adaptation to these changes;

- using pricing as a mechanism for influencing and responding to market conditions;

- selection of effective forms and methods of delivery, advertising and sales of products;

- supporting the creative atmosphere among the employees involved in marketing activities, encouragement of their activity and initiative in the development of marketing decisions.

\section{Conclusion}

Consequently, the commodity policy of an enterprise is one of the most important and complex areas of marketing activity that is carried out within the definition and satisfaction of the needs of consumers as a means of achieving the strategic and tactical goals of the enterprise and is associated with the development and introduction of new products, servicing existing products and removing outdated goods .

Marketing commodity policy consists of three parts: product development (creation of a new product or modification of existing ones); Service maintenance (ensuring the stability of the relevant characteristics of the goods in demand, especially important is the product quality control at all stages - from design to sale) and elimination (goods removal from production).

In market conditions, the main factors that determine the formation of a commodity policy of an enterprise are the consumer preferences and the internal production potential of the enterprise. The results of marketing control of management of marketing commodity policy, namely: analysis of the product potential of the enterprise contribute to the formation of change strategies in the management of marketing commodity policy. With this in mind, the following strategies are distinguished: support strategy, modification strategy and update strategy.

\section{REFERENCES}

1. Butenko N.V. Fundamentals of Marketing: Teach. manual. / N.V. Butenko. - K.: Publ.- polygraphic center «Kyiv University», 2004. - 140 p. [in Ukrainian]

2. Illyashenko S.M.. Marketing commodity policy of an industrial enterprise: management of diversification strategies : monography / S.M. Illyashenko, G. O. Peresadko; by

comp. ed. of S. M. Illyashenko. - Sumy : University book, 2009.- 328 p. [in Ukrainian]

3. Voychak A.V. Marketing Management: Textbook / Voychak A.V. - K. : KNEU, 1998. - 268 p. [in Ukrainian]

4. Garkavenko S.S. Marketing: Textbook / Garkavenko S.S. - K: Libra, 2002. - 712p. [in Ukrainian]

5. Kholodnuy G.O. Marketing Commodity Policy: Teach. manual / Kholodnuy G.O. - Kharkiv : Publ. KhNEU, 2006. 324 p. [in Ukrainian]

6. Balabanova L.V. Marketing commodity policy in the system of enterprise management: teachers' manual / Balabanova L.V. - K. : Publ. "Professional", 2006. - 336 p. [in Ukrainian]

7. Krikavskiy E.V. Marketing Commodity Policy: Teach. manual. / Krikavskiy E.V. - Lviv : Published by NU "Lviv Polytechnic", 2008. - 276 p. [in Ukrainian]

8. Ptaschenko $O$. V. Formation of marketing support for commodity innovation policy //BUSINESSINFORM. - 2012. - № 7. - P. 160-162. [in Ukrainian]

9. Rozhko $N$. The main intentions of choosing a marketing strategy for marketing by an industrial enterprise / N. Rozhko [Electronic resource]. - Access mode: //http://elartu.tntu.edu.ua/ bitstream/lib/21173/2/SEIED_2017_Rozhko_N-Basic_ directions_of_choice_62-64.pdf

10. Marketing: Textbook / W.Rudelius, O. M. Azaryan, N. O. Babenko and others -3-rd ed.- K.: Educational and Methodological Center «Consortium for the Improvement of Management Education in Ukraine». 2008.- 648.p. [in Ukrainian]

11. Karpenko V.L. Genesis of the concept of «marketing commodity policy» in the Ukrainian economic literature // Journal of the Khmelnytsky National University. - 2011. - № 6, B.2. P. 62-65. [in Ukrainian]

12. Sydorenko K. E. Marketing commodity policy of the enterprise and ways for its improvement / K. E. Sydorenko, O. S. Korpan [Electronic resource]. - Access mode://http:// nauka.kushnir.mk.ua/?p=68049 


\section{ОСНОВНІ СТРАТЕГІЇ РОЗВИТКУ МАРКЕТИНГОВОЇ ТОВАРНОЇ ПОЛІТИКИ}

\section{Авраменко А.І., Кучкова О.В.}

У статті розглянуто теоретичні підходи стосовно визначення сутності категорії маркетингова товарна політика.. Сформульовано завдання, структуру та основні складові товарної політики в сучасних економічних умовах. Проаналізовано основні цілі маркетингової товарної політики. Запропоновано стратегії змін в управлінні маркетинговою товарною політикою підприємства, а саме: стратегію підтримки, стратегію модифікації і стратегії відновлення, що сприятиме підвищенню конкурентоспроможності товарів, товарного портфеля підприємства, і його іміджу. Маркетингова товарна політика складається з трьох частин: розробка товару (створення нових чи модифікація існуючих); обслуговування товару (забезпечення сталості відповідних характеристик товару, що користується попитом, особливо важлливим є контроль за якістю продукції на всіх етапах - від розробки до продажу) та елімінування (зняття товару з виробництва).

Ключові слова: товар, товарна політика, маркетингова товарна політика, стратегія, товарна стратегія

\section{ОСНОВНЫЕ СТРАТЕГІИ РАЗВИТИЯ МАРКЕТИНГОВОЙ ТОВАРНОЙ ПОЛИТИКИ}

Авраменко А.И., Кучкова О.В.

В статье изложено подходы ученых относительно определения сущности категории маркетинговая товарная политика. Рассмотрены теоретический аспект маркетинговой товарной политики. Сформулированы задачи, структура и основные составляющие товарной политики в современных экономических условиях. Проанализированы основные цели маркетинговой товарной политики. Предложены стратегии изменений в управлении маркетинговой товарной политикой предприятия, а именно: стратегию поддержски, стратегию модификации и стратегии обновления, что способствует повышению конкурентоспособности товаров, товарного портфеля предприятия, и его имиджа. Маркетинговая товарная политика состоит из трех частей: разработка товара (создание новых или модификация существующих) обслуживание товара (обеспечение устойчивости соответствующих характеристик товара, пользующегося спросом, особенно важным является контроль за качеством продукции на всех этапах - от разработки до продажи) и элиминирования (снятие товара с производства).

Ключевые слова: товар, товарная политика, маркетинговая товарная политика, стратегия, товарная стратегия. 